\title{
Peningkatan Performa Budidaya Lele Dumbo (Clarias gariepinus, Burch) Di Desa Serut Kecamatan Panti Kabupaten Jember Provinsi Jawa Timur
}

\author{
Mukhamad Su'udi, Syubbanul Wathon \\ Jurusan Biologi, Fakultas Matematika dan Ilmu Pengetahuan Alam, Universitas Jember \\ msuudi.fmipa@unej.ac.id
}

\begin{abstract}
Abstrak
Lele dumbo merupakan jenis ikan lele yang memiliki beberapa keistimewaan dan banyak diminati masyarakat. Hal ini karena pada dasarnya budidaya lele dumbo tidak memerlukan lahan khusus, modal yang tidak terlalu besar, tidak memerlukan air dalam jumlah banyak, mudah dipelihara dan pertumbuhannya cepat. Rasa daging yang lezat dan gurih membuat bisnis budidaya lele dumbo menjadi peluang usaha yang cukup menjanjikan keuntungan. Budidaya lele dumbo sudah dikenal dan dijadikan lahan bisnis di berbagai daerah, termasuk di desa Serut kecamatan Panti kabupaten Jember. Namun seiring berjalannya waktu, beberapa kendala dihadapi oleh kelompok tani lele dumbo tersebut, diantaranya adalah penggunaan pakan yang terlalu boros, harga pakan yang mahal, adanya serangan penyakit serta pembesaran lele yang tidak merata. Kendala-kendala ini perlu diselesaikan dengan pengetahuan dan penerapan teknologi sederhana untuk meningkatkan performa budidaya. Adanya pendekatan dengan kelompok karang taruna dan kelompok ternak melalui metode komunikasi, diskusi dan bekerja secara sinergi, tim dapat merealisasikan hasil dan luaran, antara lain: pembuatan kolam dan kelengkapannya, workshop dan pelatihan, pembuatan pakan alternatif beserta cara pemberian pakan, serta wacana pengembangan budidaya lele pada program pengabdian, kemitraan atau program lain yang berkaitan, dan simulasi capaian jangka panjang untuk budidaya lele di desa Serut kecamatan Panti, kabupaten Jember. Melalui program ini, performa lele meningkat sehingga dapat meningkatkan penghasilan petani lele sekaligus dapat meningkatkan skala budidaya serta dapat membuka peluang usaha mandiri penduduk sekitar. Tidak hanya itu, keberhasilan peningkatan performa budidaya lele dumbo di Desa Serut dapat menjadi desa model percontohan bagi kawasan lainnya untuk mengembangkan usaha budidaya lele dumbo dengan cara yang tepat.
\end{abstract}

Kata Kunci: Budidaya, Lele Dumbo, Mitra, Performa.

\section{PENDAHULUAN}

Perikanan merupakan salah satu sektor yang dapat menunjang pembangunan perekonomian di Indonesia. Sumber daya perikanan yang dimiliki oleh Indonesia beragam dan berpotensi diantaranya perikanan hasil tangkap dan perikanan budidaya. Teknik pembudidayaan ikan yang dikenal di Indonesia antara lain pembudidayaan ikan di kolam air deras, kolam air tenang dan keramba (Situmorang, 2016). Salah satu jenis usaha budidaya perikanan darat yang menjadi komoditas unggulan dan banyak dibudidayakan oleh masyarakat adalah ikan lele (Mardinawati et al. 2011). Dari segi kebutuhan pakan, ikan lele memiliki perbandingan rasio pakan menjadi daging berkisar 1:1, yaitu dalam penambahan pakan sebanyak $1 \mathrm{~kg}$ akan menghasilkan $1 \mathrm{~kg}$ pertambahan berat ikan lele (Sudana et al., 2013). 
Lele dumbo (Clarias gariepinus, Burch) merupakan salah satu jenis ikan lele yang memiliki beberapa keistimewaan dan banyak diminati masyarakat. Budidaya ikan lele dumbo mempunyai prospek yang sangat cerah. Hal ini karena pada dasarnya budidaya lele dumbo tidak memerlukan lahan khusus, modal yang tidak terlalu besar, tidak memerlukan air dalam jumlah banyak, mudah dipelihara dan pertumbuhannya cepat (Rosalina, 2014). Rasa daging yang lezat dan gurih membuat bisnis budidaya lele dumbo menjadi peluang usaha yang cukup menjanjikan keuntungan (Sudana et al., 2013). Dengan demikian, peningkatan usaha budidaya ikan lele dumbo semakin tinggi karena budidaya ikan lele dumbo dapat menciptakan lapangan kerja, meningkatkan pendapatan, tingginya permintaan pasar akan ikan lele, peningkatan kemampuan berusaha dan dapat memenuhi kebutuhan gizi masyarakat, terutama yang berasal dari ikan (Khairuman, 2002).

Kawasan di Kabupaten Jember memiliki potensi yang baik untuk dikembangkan berbagai jenis ikan air tawar. Bersadarkan data pada Tabel 1 (Produksi dan nilai ikan air tawar di Kabupaten Jember menurut jenisnya tahun 2013), ternyata komoditas ikan lele memiliki tingkat produksi dan nilai tertinggi dibandingkan ikan air tawar lainnya. Hal ini mengindikasikan bahwa budidaya ikan lele memiliki daya tarik bagi masyarakat Jember untuk mengusahakannya. Desa Serut yang terletak di Kecamatan Panti Kabupaten Jember memiliki potensi besar untuk dijadikan lahan baru untuk pengembangan budidaya lele dumbo. Hal ini cukup beralasan kuat, karena Desa Serut di Kecamatan Panti memiliki luas lahan pertanian dan perkebunan yang cocok untuk dijadikan lahan budidaya lele. Sejauh ini, masih banyak lahan yang belum dimanfaatkan secara optimal, khususnya lahan perkebunan yang hanya ditanami semak belukar. Kondisi lingkungan yang tidak terlalu panas dan kering sangat memungkinkan untuk dijadikan lokasi budidaya lele. Selain itu, sumber mata air sangat mencukupi untuk memenuhi kebutuhan air untuk budidaya lele.

Tabel 1. Produksi dan Nilai Ikan Air Tawar Menurut Jenisnya di Kabupaten Jember Tahun 2013

\begin{tabular}{clrr}
\hline No. & Jenis Ikan & Produksi (Ton) & Nilai (Rupiah) \\
\hline 1. & Ikan Mas & 72,40 & 2.279 .500 \\
2. & Ikan Nila & 188,50 & 2.668 .500 \\
3. Ikan Gurame & 1182,40 & 31.301 .150 \\
4. & Ikan Lele & 3285,20 & 45.668 .750 \\
5. Ikan Tawas & 37,60 & 355.700 \\
6. Ikan Mujair & 27,40 & 191.800 \\
7. Ikan Lain & 38,30 & 493.400 \\
\hline Jumlah & 4831,80 & $\mathbf{8 2 . 9 5 8 . 8 0 0}$ \\
Rata-rata & 690,26 & $11.851 .257,14$ \\
\hline
\end{tabular}

Beberapa kelompok masyarakat yang terhimpun dalam Karang Taruna Bolo Dewo, Kelompok Ternak Sejahtera Bersama, dan Kelompok Ternak Pos Daya Semarak 11 telah menginisiasi usaha budidaya lele dumbo di Desa Serut. Usaha tersebut telah berjalan sekitar 2 tahun. Seiring berjalannya waktu ternyata usaha ini terhambat oleh beberapa kendala, diantaranya adalah penggunaan pakan yang terlalu boros, harga pakan yang mahal, adanya serangan penyakit (sirip merah yang disebabkan oleh serangan virus dan cacar yang disebabkan oleh jamur) serta pembesaran lele yang tidak merata. Kendala-kendala ini perlu diselesaikan dengan pengetahuan dan penerapan teknologi sederhana untuk meningkatkan performa budidaya. 
Kondisi yang demikian menarik perhatian civitas akademik Tim Dosen Jurusan Biologi FMIPA Universitas Jember melalui Program Kemitraan Masyarakat (PKM) untuk turut terjun di masyarakat dalam menyelesaikan permasalahan yang dihadapai petani lele di Desa Serut. Adanya program ini sebagai wujud nyata kegiatan pengabdian kepada masyarakat yang merupakan bagian dari Tri Dharma Perguruan Tinggi. Peningkatan performa budidaya lele dumbo di Desa Serut Kecamatan Panti Kabupaten Jember diharapkan dapat meningkatkan penghasilan petani lele sekaligus dapat meningkatkan skala budidaya sehingga dapat membuka peluang usaha mandiri penduduk sekitar. Tidak hanya itu, keberhasilan peningkatan performa budidaya lele dumbo di Desa Serut dapat menjadi desa model percontohan bagi kawasan lainnya utk mengembangkan usaha budidaya lele dumbo.

Kelompok masyarakat yang terhimpun dalam Karang Taruna Bolo Dewo, Kelompok Ternak Sejahtera Bersama dan Pos Daya Semarak 11 selain menjalankan usaha budidaya lele dumbo juga melakukan kegiatan sosial membantu Rumah Yatim Piatu yang ada di Desa Serut. Sebagian hasil dari usaha budidaya didonasikan ke Rumah Yatim Piatu. Adanya kegiatan luaran ini menunjukkan bahwa usaha budidaya lele juga telah membantu masyarakat khususnya Rumah Tangga Yatim Piatu di Desa Serut. Dengan demikian, kegiatan PKM ini tidak hanya meningkatkan performa budidaya lele dumbo di desa serut, meningkatkan pendapatan petani lele, meningkatkan skala usaha serta memungkinkan untuk membuka lapangan usaha bagi penduduk sekitar, lebih jauh lagi sebagai bukti nyata kegiatan sosial membantu Rumah Yatim Piatu di Desa Serut Kecamatan Panti, Kabupaten Jember.

\section{METODE PELAKSANAAN}

Metode yang digunakan untuk mengatasi permasalahan pada mitra adalah sebagai berikut:

\section{A. Sosialisasi}

Sosialisasi program dilakukan untuk menyampaikan maksud dan tujuan kegiatan oleh tim pengusul kepada mitra. Tim pengusul PKM memaparkan latar belakang dilakukan program PKM ini kemudian merancang peralatan serta jenis pelatihan dan pendampingan yang dibutuhkan oleh mitra untuk mencapai target luaran yang dimaksud. Sebagai bentuk timbal balik, mitra menyediakan tempat sosialisasi dan pelatihan, mengundang rekan-rekan sesama penggiat usaha serupa, dan juga berhak mengusulkan ahli/ narasumber yang akan diundang untuk mengisi pelatihan. Rangkaian kegiatan dilaksanakan berdampingan dengan mitra sebagai bentuk partisipasi mitra dalam PKM.

\section{B. Pemberian modal usaha}

Modal usaha diberikan dalam bentuk peralatan yang dibutuhkan dan dapat memecahkan permasalahan yang ada. Tim pengusul PKM akan merancang kolam terpal atau tembok dilengkapi biofilter yang digunakan untuk tempat pembesaran lele dumbo dengan tambahan aerator sederhana serta dilengkapi saluran pengurasan air. Tim pengusul merancang peralatan tersebut sesuai dengan kebutuhan mitra dengan mempertimbangkan masukan dari mitra.

\section{Pelatihan}

Pelatihan dilakukan untuk meningkatkan pengetahuan dan pemahaman mitra terhadap penggunaan kolam terpal atau tembok dengan biofilter dan aerator sederhana serta dilengkapi saluran pengurasan air. Teknis penggunaan peralatan dijelaskan dengan detil hingga mitra paham dan dapat menggunakannya secara mandiri. 
Peningkatan pemahaman akan pemberian pakan alami, teknik sorting lele berpenyakit, sorting lele berdasarkan umur dan ukuran dilakukan dengan mendatangkan narasumber di bidang Perikanan dan Peternakan yang berasal dari Universitas dan Balai/ Lembaga Penelitian sekitar. Selain itu, juga dilakukan pelatihan mengenai pengetahuan dan keterampilan mengenai manajemen pemasaran (pasca panen) sederhana dengan mendatangkan narasumber dari bidang Perikanan dan Agribisnis.

\section{Peningkatan pemahaman}

Peningkatan pemahaman dilakukan dengan memberi pengetahuan awal, pemahaman, serta penerapan teori yang telah diberikan. Teori diberikan dengan metode ceramah, diskusi dan praktek, dengan menggunakan alat bantu viewer, alat peraga dan contoh-contoh yang diperlukan. Selanjutnya, peningkatan pemahaman dan keterampilan dilakukan dengan mengukur pemahaman dan keterampilan mitra menggunakan instrumen pre test dan post test.

\section{E. Pendampingan}

Tim pengusul PKM mendampingi mitra dalam penggunaan kolam terpal atau tembok biofilter beraerator sederhana untuk pembesaran lele dumbo dan dilengkapi dengan saluran penguras air, penerapan hasil penyuluhan dan pembimbingan tentang penambahan pakan alami lele dumbo, teknik sorting lele berpenyakit dan soring lele berdasarkan umur dan ukuran, serta penerapan manajemen pemasaran (pascapanen). Pendampingan dilakukan hingga mitra dapat melaksanakannya secara mandiri. Pendampingan dilakukan dengan supervisi penerapan keterampilan yang diberikan dalam teori untuk memastikan keterampilan dapat diimplementasikan di lapangan.

Dampak dari segi ekonomi yang diharapkan dari kegiatan ini yaitu meningkatnya performa budidaya lele dumbo yang akan meningkatkan pendapatan petani lele. Selain dampak ekonomi, dampak bidang sosial adalah adanya donasi dana hasil budidaya lele dumbo untuk Rumah Yatim Piatu. Dampak di bidang ipteks yang diharapkan yaitu terjadinya transfer ilmu (alih teknologi) antara PT dengan masyarakat.

\section{HASIL DAN LUARAN YANG DICAPAI}

Program pengabdian masyarakat peningkatan performa budidaya lele dumbo yang telah dilaksanakan di dusun Karanganom, desa Serut kecamatan Panti Jember, meliputi beberapa hasil dan luaran, antara lain: pembuatan kolam dan kelengkapannya, workshop dan pelatihan, pembuatan pakan alternatif dan cara pemberian pakan, serta wacana pengembangan budidaya lele pada program pengabdian, kemitraan atau program lain yang berkaitan, dan simulasi capaian jangka panjang untuk budidaya lele di desa Serut kecamatan Panti, kabupaten Jember.

\section{A. Pembuatan Kolam}

Kolam terpal dan kolam tembok (semen/ beton) merupakan dua jenis kolam yang paling sering digunakan untuk budidaya lele secara intensif. Kolam terpal adalah kolam yang dinding dan dasarnya terbuat dari terpal, dibentuk dengan penyangga dari kayu, bambu, atau rangka besi. Kolam terpal dipilih karena murah dan bisa digunakan di lahan sempit. Namun demikian, kolam terpal banyak memiliki kekurangan, antara lain: 1) terpal berpotensi robek dan mengalami kebocoran, 2) kolam terpal tidak permanen dan lebih cepat aus jika sering terpapar sinar matahari, 3) pemberian makanan tambahan lebih banyak karena kolam terpal mengandung sedikit unsur hara, 4) perlu dilakukan pengurasan lebih sering untuk menjaga kualitas air, karena kotoran dalam kolam berpotensi masih menempel/mengendap di bagian lipatan-lipatan terpal terutama pada bagian bawah, dan 5) kolam terpal akan mengalami penurunan kualitas 
seiring usia dan frekuensi pemakaian, sehingga pada akhirnya para pembudidaya lele harus membeli lagi terpal yang baru.

Setelah melakukan kajian terhadap beberapa jenis kolam untuk budidaya lele, maka pada program kemitraan kali ini, kolam terpal hanya digunakan untuk proses awal budidaya, yaitu untuk pembesaran benih lele sampai tahap sortasi. Sortasi dilakukan dengan tujuan agar lele yang dipindah ke kolam pembesaran memiliki ukuran yang seragam. Untuk tahap pembesaran lele sampai mencapai ukuran konsumsi, dilakukan pada kolam tembok. Meskipun kolam tembok memerlukan biaya awal yang lebih banyak dari kolam terpal, kolam tembok memiliki keunggulan yang banyak. Beberapa keunggulan dari kolam tembok antara lain: 1) tahan lama dan tidak mudah mengalami kebocoran, 2) lebih tahan terhadap tekanan air kolam, 3) permanen, tidak mudah rusak dan tahan terhadap cuaca, 4) pemberian pakan lebih efisien karena lele bisa mendapatkan pakan alami dari dalam kolam, 5) pengontrolan air lebih mudah dan terkontrol, 6) sistem pembuangan sisa metabolisme lele sangat mudah dilakukan dengan sistem drainase sentral, dan 7) dengan perawatan yang tepat, kolam tembok bisa digunakan secara terus menerus tanpa dibayangi kerusakan yang sering terjadi pada kolam terpal. Budidaya dengan kolam tembok sangat tepat digunakan untuk tujuan jangka panjang. Sebagaimana dalam program ini, sebagian hasil yang didapatkan dari budidaya lele di desa Serut dialokasikan untuk santunan anak-anak yatim yang berada di lokasi setempat. Kolam tembok yang sudah dibuat sangat bermanfaat bagi mitra untuk budidaya lele berkesinambungan yang secara tidak langsung juga memiliki efek positif dan berkelanjutan terhadap program santunan anak yatim.
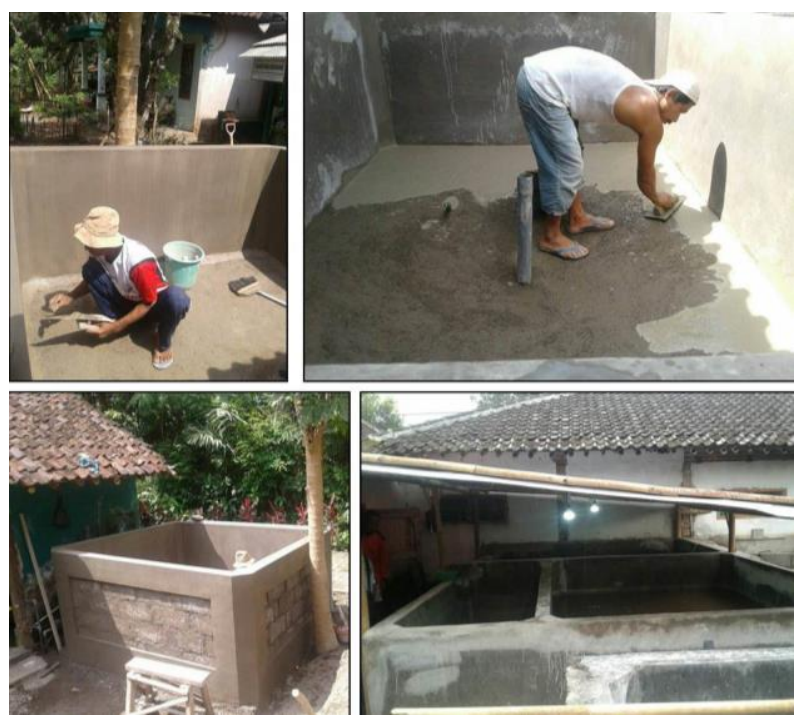

Gambar l. Pembuatan kolam tembok untuk budidaya lele dumbo kelompok mitra pengabdian.

Kolam tembok yang dibuat untuk peningkatan peforma budidaya lele disesuaikan dengan jumah mitra yaitu sebanyak tiga kolam yang masing-masing berukuran 3 x 2 meter (panjang x lebar) dengan tinggi 1-1,2 meter (Gambar 1). Masingmasing mitra (Karang Taruna Bolo Dewo, kelompok ternak Sejahtera Bersama, dan kelompok ternak Pos Daya Semarak) mendapatkan satu kolam tembok yang dilengkapi sistem drainase sentral dan dilengkapi dengan perlengkapan standar budidaya lele seperti aerator dan sesh. Mitra juga mendapatkan bibit lele dumbo berukuran antara 57, pakan dan probiotik. 


\section{B. Workshop dan Pelatihan}

Workshop dan pelatihan diperlukan sebagai salah satu bentuk kegiatan yang terkoordinasi dengan tujuan untuk transfer pengetahuan (alih teknologi), sharing, diskusi dan pembekalan terhadap mitra dan anggotanya dalam menjaga komitmen dalam program peningkatan performa budidaya lele dumbo. Dalam kegiatan ini, setiap peserta mendapatkan modul yang berisi teknik budidaya lele dumbo yang dilengkapi dengan ilustrasi untuk memudahkan pemahaman. Workshop dilakukan di salah satu posko mitra yaitu di kelompok Karang Taruna Bolo Dewo, dusun Karanganom desa Serut - Panti, Jember (Gambar 2).

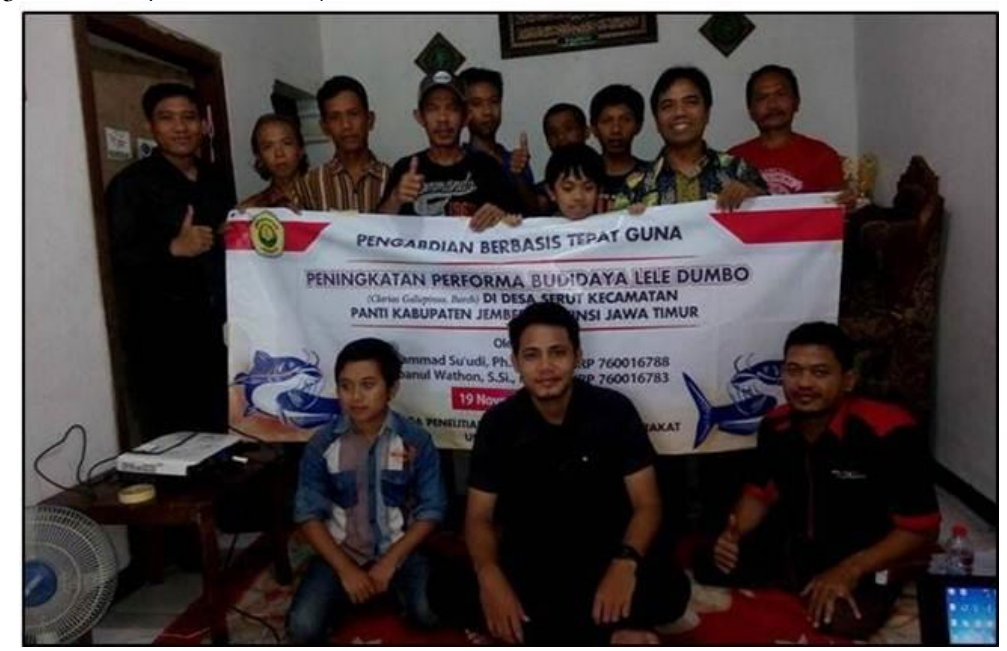

Gambar 2. Kegiatan workshop budidaya lele dumbo posko mitra pengabdian.

Dalam workshop ini, sebagian besar peserta bisa memahami proses budidaya lele yang benar mulai dari teknik pemilihan dan pembuatan kolam, pemilihan bibit lele, teknik sortasi, pengaturan dan kontrol air kolam, pemilihan pakan alternatif untuk menekan biaya pakan, dan simulasi pasca panen lele. Setelah workshop dan pelatihan, mitra langsung bisa mengaplikasikan sesuai dengan modul yang diberikan dan penjelasan yang telah dipaparkan. Selain itu, peserta diharuskan untuk memberikan pendapat, saran atau kritik secara lisan atau tertulis setelah kegiatan workshop dilaksanakan. Seluruh peserta memberikan kesan yang sangat positif terhadap kegiatan workshop ini. Sebagian besar mengharapkan kegiatan workshop atau pelatihan dilaksanakan secara berkesinambungan dan terjadwal. Sedangkan peserta yang lain mengharapkan adanya pendampingan selama dan sesudah program kemitraan ini dilaksanakan.

\section{Pembuatan dan Pemberian Pakan Alternatif}

Selain pengontrolan kualitas air, pakan merupakan salah satu bagian terpenting dalam proses pembesaran lele intensif dan memiliki kontribusi $70-80 \%$ biaya produksi. Secara umum, pakan lele dibedakan menjadi pakan alami, pakan buatan, dan pakan alternatif. Pakan alami adalah pakan yang secara alami sudah tersedia di dalam kolam pembesaran. Teknik pemberian pakan alami ini biasa diaplikasikan pada budidaya secara tradisional menggunakan kolam tanah. Contoh pakan alami adalah plankton, cacing, dan hewan atau tumbuhan-tumbuhan kecil yang secara alami berada di kolam tanah tersebut atau terbawa air yang masuk pada kolam tanah. Namun realita yang ada saat ini, sistem budidaya lele dengan pakan alami jarang ditemukan karena jumlah lele yang dipanen sangat berkurang dari jumlah bibit awal yang dimasukkan, yang berarti bahwa lele membutuhkan jumlah pakan yang lebih banyak dan pakan alami yang ada 
tidak cukup memenuhi kebutuhan pakan lele. Sehingga yang terjadi adalah sifat kanibal lele muncul dan memakan lele yang berukuran kecil dan lemah.

Pakan buatan merupakan pakan hasil produksi pabrik yang biasanya berupa pelet atau sentrat dan didesain untuk mencukupi kebutuhan asupan nutrisi lele. Pelet tersedia dalam berbagai jenis dan ukuran yang bisa disesuaikan dengan umur ikan. Pakan buatan ini mengandung nutrisi lengkap seperti protein, lemak, karbohidrat, vitamin dan mineral. Protein yang terkandung pada pakan buatan berkisar 30-40\% yang sudah disesuaikan dengan kebutuhan nutrisi lele. Protein tersebut biasanya bersumber dari bahan dasar tepung ikan. Namun demikian, semakin tingginya harga pakan pelet seringkali menjadi kendala dalam budidaya pembesaran lele. Sehingga dalam praktek di lapangan, sangat jarang pembudidaya yang pemberian pakannya $100 \%$ hanya pakan pelet. Kondisi seperti ini juga terjadi pada peternak lele di dusun Karanganom, desa Serut - Panti, Jember. Salah satu cara terbaik yang bisa dilakukan dalam proses pemberian pakan lele adalah dengan tetap memberi pakan buatan pabrik namun disertai dengan pemberian pakan alternatif.

Pakan alternatif bisa meminimalisasi biaya pakan. Pakan alternatif bisa berupa pakan alami yang mudah ditemui di lokasi budidaya, seperti bekicot, keong mas, cacing darah, maggot, ikan rucah, limbah peternakan/ pemotongan hewan. Selain itu, pakan alternatif bisa berasal dari bungkil kelapa, ampas tahu, bekatul, daun papaya, dan beberapa jenis tumbuhan tingkat rendah seperti Azolla, kiambang dan Lemna minor. Salah satu syarat pakan alternatif yang disarankan adalah ketersediaan bahan yang berkelanjutan, yang berarti bahwa bahan untuk pembuatan pakan alternatif bisa didapatkan dengan mudah di sekitar lokasi budidaya. Hal ini diperlukan agar pakan alternatif lele tidak berubah-berubah yang bisa menyebabkan lele mengalami stres. Selain itu, tersedianya bahan untuk pembuatan pakan alternatif di sekitar lokasi bisa mengurangi biaya transportasi.

Di lokasi mitra kali ini, beberapa bahan pakan alternatif yang mudah didapatkan di sekitar lokasi antara lain ampas tahu, bekatul, tepung kedelai, daun papaya, dan Azolla. Formulasi pakan alternatif ditampilkan pada Tabel 2. Bahan-bahan tersebut dicampurkan dengan tepung ikan, tepung bulu, dan minyak ikan, kemudian diproses (fermentasi) dengan cara mencampurkan dengan EM4 (Gambar 3). Setelah terjadi fermentasi, kemudian dibentuk seperti kepalan tangan dan bisa langsung diberikan pada lele. Formulasi campuran pakan alternatif tersebut disesuaikan dengan kebutuhan lele dan kandungan nutrisi (protein) bisa diprediksi dengan cara memperhatikan persentasi bahan. Dari komposisi tersebut, perkiraan protein yang terkandung pada pakan alternatif adalah $\pm 29 \%$.

Tabel 2. Komposisi bahan untuk pembuatan pakan alternatif

\begin{tabular}{|c|c|c|}
\hline No. & Jenis Bahan & Jumlah \\
\hline 1. & Tepung ikan & $20 \%$ \\
\hline 2. & Tepung kedelai & $3 \%$ \\
\hline 3. & Dedak halus/ bekatul & $2,4 \%$ \\
\hline 4. & Ampas tahu & $2,3 \%$ \\
\hline 5. & Tepung bulu & $1,5 \%$ \\
\hline 6. & Ampas kelapa & $0,6 \%$ \\
\hline 7. & Tetes & $1 \mathrm{~L}$ \\
\hline 8. & EM4 & $0,5 \mathrm{~L}$ \\
\hline
\end{tabular}




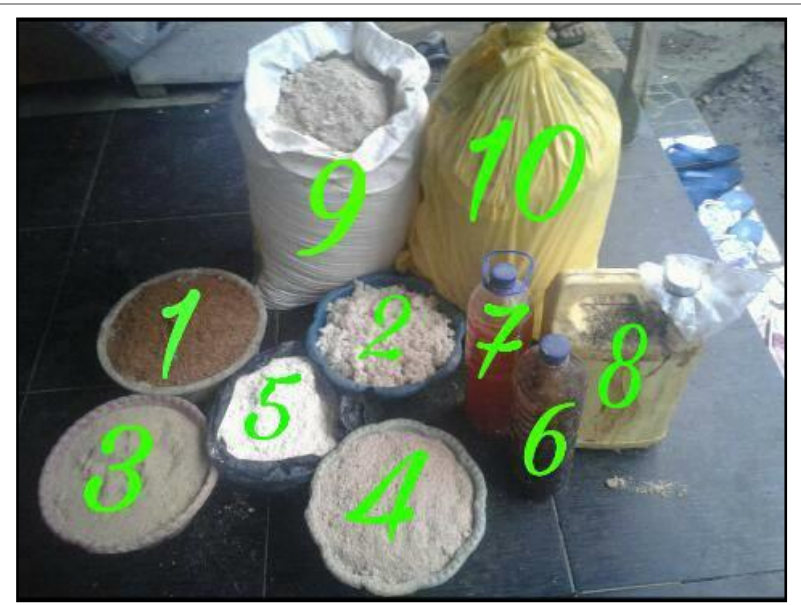

Gambar 3. Bahan-bahan yang dipakai untuk formulasi pakan alternatif adalah: 1.

Tepung ikan, 2. Ampas tahu, 3. Tepung kedelai, 4. Dedak, 5. Tepung bulu, 6. EM4, 7-8. Gula merah/ tetes, 9. Ampas kelapa, 10. Bahan yang sedang diproses (fermentasi).

\section{Capaian Keseluruhan}

Secara umum, capaian peningkatan performa budidaya lele dumbo yang telah dilaksanakan di dusun Karanganom, desa Serut kecamatan Panti Jember sudah sesuai dengan program yang direncanakan. Capaian tersebut meliputi pembuatan kolam dan kelengkapannya, workshop dan pelatihan, serta pembuatan pakan alternatif. Meskipun ada sedikit kendala pada awal program ini: seperti hujan yang mengganggu ketika pembuatan kolam, sehingga berdampak pada lambatnya pemanenan, namun secara umum proses pembesaran lele dumbo dan pengaturan air mengalami peningkatan performa. Performa tersebut meliputi: kemudahan pengaturan kualitas air, menurunnya jumlah ikan yang terserang penyakit, pertumbuhan ikan yang semakin baik dan cepat (Gambar 4) serta pembuatan pakan alternatif sehingga bisa menekan biaya pakan selama proses pembesaran lele sampai tahap pemanenan.
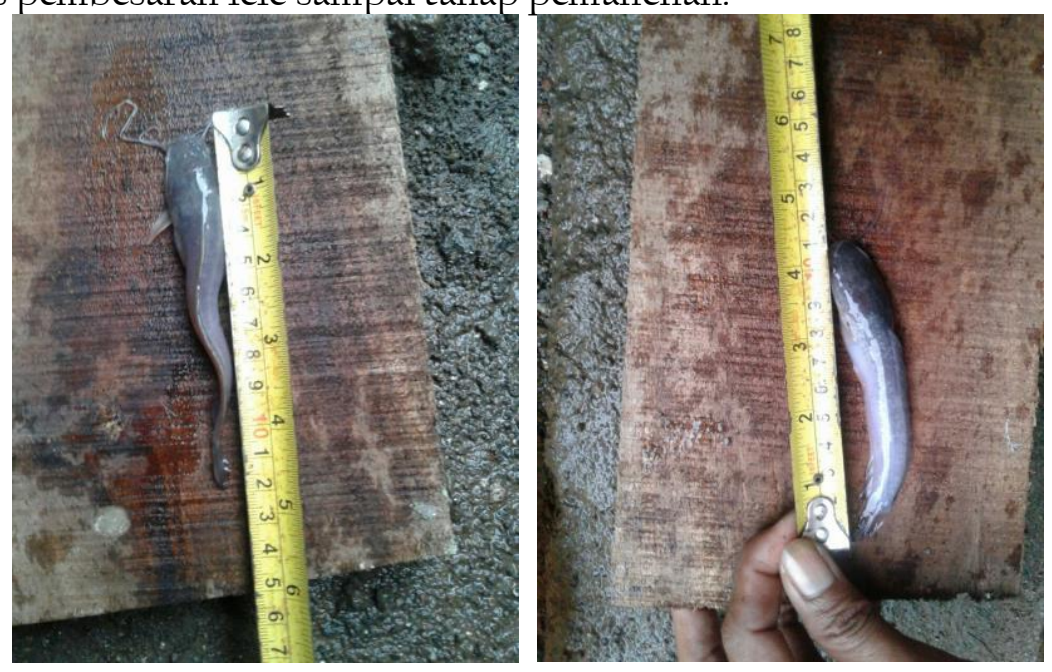

Gambar 4. Lele dumbo berumur 28 hari hasil program kemitraan (kiri) dibandingkan dengan lele dumbo berumur 40 hari yang dibesarkan dengan menggunakan kolam terpal (kanan).

\section{KESIMPULAN}

Berdasarkan hasil yang diperoleh dari program pengabdian berbasis teknologi tepat guna ini dapat ditarik kesimpulan bahwa kegiatan pengabdian ini bisa menambah wawasan masyarakat tentang budidaya lele dumbo yang tepat, mulai dari pemilihan 
jenis kolam, pemilihan bibit lele, tip dalam pembuatan pakan alternatif dan teknik pemberian pakan, serta teknik pembesaran lele sampai pemanenan yang benar. Selain itu, dari program ini dihasilkan tiga kolam tembok yang bisa dimanfaatkan oleh mitra untuk budidaya lele secara kontinyu yang pada akhirnya dapat meningkatkan penghasilan warga dan mendukung program santunan anak yatim secara berkelanjutan. Pembuatan pakan alternatif bisa menjadi salah satu solusi dalam mensiasati pakan pabrikan yang mahal. Adanya kolam tembok untuk budidaya dan wawasan tentang pakan alternatif tersebut bisa menjadi salah satu investasi kemitraan dalam melaksanakan program pengabdian di waktu mendatang.

\section{DAFTAR PUSTAKA}

Alex S. Prospek cerah budidaya lele organik (Yogyakarta: Pustaka Baru Press, 2011).

Avianto D. Jurus ampuh anti gagal dalam pembesaran ikan lele (Yogyakarta: Lily Publisher, 2010).

Ghufran M. Kiat sukses pembesaran lele unggul (Yogyakarta: Lily Publisher, 2012).

Gunawan S. 99\% sukses budidaya lele (Jakarta: Penebar Swadaya, 2016).

Khairuman. Budidaya lele dumbo secara intensif (Jakarta: Argo Media Pustaka, 2002).

Mardinawati, Serdiati \& Yoel N. "Pemberian pakan yang berbeda terhadap pertumbuhan dan kelangsungan hidup benih lele dumbo (Clarias galiepinus)" (2011) (2) : 83 - 87 Media Litbang Sulteng.

Rosalina D. "Analisis kelayakan usaha budidaya ikan lele di kolam terpal di Desa Namang Kabupaten Bangka Tengah” (2014) 6(1), 20-24 Maspari Journal.

Situmorang B. "Efisiensi pengiriman benih ikan lele dumbo (Clarias gariepinus) dengan kepadatan yang berbeda dalam packing tukka-kota Pinang" (2016) 5(2) : 1 - 11 Jurnal Ilmu Sosial. dan Humaniora.

Sudana S N, Arga I W \& Suparta N. "Kelayakan usaha budidaya ikan lele dumbo (Clarias gariepinus) dan pengaruhnya terhadap tingkat pendapatan petani ikan lele di Kabupaten Tabanan" (2013) 1(1): 1-18 Jurnal Management Agribisnis.

Suyanto SR. Budidaya ikan lele. Jakarta: Penebar Swadaya, 2011). 